\title{
Dissecting Electoral Support for the Far Right: A Comparison between Mature and Post-Communist European Democracies
}

\author{
Tobias Brils, Jasper Muis* (D) and Teodora Gaidytè \\ Department of Sociology, Vrije Universiteit Amsterdam, Amsterdam, the Netherlands \\ ${ }^{\star}$ Corresponding author. E-mail: j.c.muis@vu.nl
}

(Received 5 July 2019; revised 19 May 2020; accepted 26 May 2020; first published online 4 August 2020)

\begin{abstract}
This article investigates three explanations for electoral support for the far right - 'cultural backlash', 'economic grievances' and 'protest voting' - in a novel way. Our main contribution is that we contrast far-right voters with voters of centre-right parties, traditional left-wing parties and abstainers. Equally innovative is the comparison between mature and post-communist democracies. Using European Social Survey data (2014-16), we conclude that anti-immigration attitudes are most important in distinguishing far-right voters from all other groups. Yet, these differences are significantly smaller in Eastern Europe. Furthermore, far-right voters are not the so-called socioeconomic 'losers of globalization': this is only true when compared with centre-right voters. Concerning protest voting, distrust of supranational governance particularly enhances far-right voting. Overall, our study concludes that more fine-grained distinctions pay off and avoid misleading generalizations about 'European far-right voters' often presented in public debates.
\end{abstract}

Keywords: far right; populist radical right; voting behaviour; anti-immigration attitudes; abstention; postcommunist democracies

Far-right parties have significantly increased their electoral support during the past decade (Mudde 2019). Although the rise of these parties has been underway in Western Europe since the early 1990s (Akkerman et al. 2016; Golder 2016), it recently became a worldwide phenomenon. The economic crisis in 2008 acted as a catalyst and generally increased these parties' performance further all over Europe (Algan et al. 2017; Kriesi and Pappas 2015; Zagórski et al. 2019). This trend has been accompanied by the electoral decline of mainstream parties from both the left and right - social democrats and Christian democrats.

Consequently, party systems of several countries went through significant changes. The far right has moved from the margins to the mainstream and disrupted long-established patterns of party competition (Mudde 2019; Norris and Inglehart 2019). At the same time, some mainstream conservatives have become

(C) The Author(s), 2020. Published by Cambridge University Press on behalf of Government and Opposition Limited. This is an Open Access article, distributed under the terms of the Creative Commons Attribution licence (http://creativecommons. org/licenses/by/4.0/), which permits unrestricted re-use, distribution, and reproduction in any medium, provided the original work is properly cited. 
far right themselves: prominent examples are Fidesz in Hungary and Law and Justice (PiS) in Poland, which initially gained electoral successes as conservative parties and then radicalized their rhetoric and policies (Bustikova 2018; Stanley 2017).

Moreover, scholars point out that the salience of the traditional socioeconomic left-right cleavage has faded over time, and the cultural divide between those who advocate open borders and those who defend border closure has become dominant (De Wilde et al. 2019; Kriesi et al. 2008). Nonetheless, it is difficult to disentangle current economic and cultural debates. A good illustration is how economic problems are instrumentalized to advocate moral positions by Fidesz. Its leader Viktor Orbán proclaimed that the economic crisis demonstrated the 'failure of liberal democracy' (Gessler and Kyriazi 2019).

Admitting the challenges far-right parties pose to liberal democracy, many scholars have investigated the profile and motives of their supporters. The literature commonly distinguishes between grievances arising from economic change, cultural conflict and political disillusionment. Similarly, this article combines three explanatory approaches and focuses on socioeconomic deprivation, opposition to progressive values (such as cosmopolitanism and multiculturalism) and protest against political elites (Golder 2016; Ivarsflaten 2008; Norris and Inglehart 2019). ${ }^{1}$

Prior research predominantly focused on Western Europe (for reviews, see Arzheimer 2018; Golder 2016; Muis and Immerzeel 2017). It concludes that the main predictor of far-right voting is nativism, particularly anti-immigration views. Attitudes pertaining to economic issues have less explanatory power (Cavallaro and Zanetti 2020). Yet, we do not know whether this is equally true in Central and Eastern Europe (hereafter: CEE). Moreover, most previous studies made a simple dichotomy between far-right voters and all other voters (e.g. Eger and Valdez 2015; Rooduijn 2017; Werts et al. 2012; Zagórski et al. 2019). The important question remains whether these conclusions hold if we do not lump all other voters together.

This article adopts an innovative approach to individual-level explanations for far-right support by making two novel comparisons. First, what distinguishes farright voters from voters for other party families and abstainers? In their comparative study of nine Western European countries, Daniel Oesch and Line Rennwald (2018) argue that three party blocs can be distinguished based on parties' ideology: the left, the centre right and the far right. Accordingly, we compare far-right voters with traditional left-wing voters (including socialist and social democratic parties) and centre-right voters (including Christian democratic and conservative parties). By doing so, our results indicate more clearly which parties compete with far-right parties on which issues. Comparing far-right supporters with moderate-right voters is interesting because of the related conservative party ideology of centre-right parties (Immerzeel et al. 2015). A comparison between far-right voters and traditional left-wing parties is equally interesting because the socioeconomic status of supporters of both types of parties is similar (Oesch and Rennwald 2018).

We also include abstainers (see Zhirkov 2014), because not all people respond to dissatisfaction with political radicalism (i.e. far-right voting). Another important option is to withdraw from political participation (Hooghe et al. 2011). Jens Rydgren (2011) defines that contrast as the choice between 'voice' and 'exit'. 
Our second contribution is that we compare mature and post-communist democracies. Are the above-mentioned three explanations for far-right voting equally valid for CEE? Our aim is thus to investigate whether the appeal of far-right parties in post-communist democracies can be explained by theories acquired from studies on mature democracies (see Allen 2017b). Until recently, scholars have often ignored the post-communist region (Minkenberg 2017; Pirro 2014a; Pytlas 2016). Some studies included both Western and Eastern European countries (e.g. Norris and Inglehart 2019), but neither explain nor demonstrate whether far-right voting is driven by the same reasons in the two regions. This comparison is interesting because of the persisting political and socioeconomic differences between the two regions, primarily inflicted by the legacy of communist rule and traumatic postcommunist transformation in CEE (Gaidyte 2015; Pop-Eleches and Tucker 2017).

Analysing attitudes and voting behaviour in 17 countries covered in the European Social Survey (ESS) in 2014 and 2016, we find that anti-immigration attitudes are most important in distinguishing far-right voters from all other groups in both mature and post-communist democracies. Yet, these differences are significantly smaller in CEE. Socioeconomic deprivation appears less important: far-right voters are not the so-called socioeconomic 'losers of globalization'; this is only true when we compare them with centre-right voters. Concerning protest voting, we show that distrust of supranational governance particularly enhances far-right voting. Distrust of national politics is, however, not systematically related to electoral support for far-right parties.

Overall, we conclude that far-right voters generally resemble non-voters and voters of traditional left-wing parties in terms of socioeconomic deprivation, and resemble those of centre-right parties where authoritarian values are concerned. In sum, our study demonstrates that more fine-grained comparisons avoid making the misleading generalizations about 'European far-right voters' often presented in public debates.

\section{Theoretical background: who votes for far-right parties?}

Scholars use different labels for the same new right party family in Europe, such as 'extreme right' (Bale 2003), 'radical right' (Arzheimer 2018) and 'populist radical right' (Rooduijn 2017). In line with, among others, Cas Mudde (2019), we use the label 'far right'. The core focus of the European far-right family is nationalism and potential threats to national values and identity (Bar-On 2018; Rydgren 2017). In this regard, far-right parties are not promoting a fundamentally different ideology from many mainstream parties, but rather adopt a more radical version of it.

It is important to stress that 'far right' does not necessarily imply 'populist'. Populism is a political discourse which puts 'the pure people' against the allegedly corrupt establishment (Mudde 2007). Who belongs to 'the people' is often only vaguely described. Whereas Jan-Werner Müller (2016:3) argues that the definition of populism implies 'an exclusionary form of identity politics', other scholars distinguish exclusionary, right-wing populism from populist parties with an inclusionary, left-wing worldview (Rooduijn 2017). In any case, it is 'misleading' to call contemporary far-right parties 'populist parties', since 'populism is not the most pertinent feature of this party family' (Rydgren 2017: 486). 


\section{'Cultural backlash': threatened national identity and traditional values}

The dominant approach for explaining far-right support focuses on what Piero Ignazi (1992) famously labelled a 'silent counter-revolution' against the rise of progressive values. Far-right parties appeal to certain segments of the population because they promote law and order, the restoration of traditional social values, 'an aggressive nationalism' and 'xenophobic policies against immigrants' (Ignazi 1992: 21). Similarly, the 'cultural backlash thesis' interprets far-right support as a reaction against sociocultural changes, such as increasing multiculturalism and the rise of libertarian values (Minkenberg 2017; Norris and Inglehart 2019). Many cultural approaches include similar arguments, but one element stands out: hostility towards immigration. Scholars sometimes adopt the broader term nativism, which can be summarized by the slogan 'own people first' (Bar-On 2018). Originally developed to analyse anti-immigrant sentiments in the US and Canada, the term has been increasingly used to understand the fortunes of the far right elsewhere (Betz 2019).

Anti-immigration attitudes can stem from both perceived symbolic threats and instrumental concerns (Lucassen and Lubbers 2012; Norris and Inglehart 2019), although citizens perhaps do not clearly distinguish between cultural and economic grievances (Golder 2016). In any case, opposition to immigration is the core motivation for people to vote for far-right parties: many scholars have demonstrated that anti-immigration attitudes constitute the main explanation for electoral support for far-right parties in Western Europe (Iversflaten 2005, 2008; Oesch 2008). The dominance of this explanatory factor is underlined by the fact that some scholars prefer the label 'anti-immigrant' parties (Van der Brug and Fennema 2007).

Tim Immerzeel and Mark Pickup (2015) argue that the supply of a nativist ideology has attracted support for the far right from people who would not otherwise turn out to vote. It can thus be assumed that abstainers feel less often that national identity is threatened than far-right voters. Empirical research on Western Europe indeed shows that anti-immigrant attitudes among far-right voters are significantly stronger than among abstainers (Zhirkov 2014).

Are electoral successes of the far right in CEE also best understood through the lens of nativism? Ethnic diversity is a prominent societal fact in the West, compared with the generally more homogeneous societies in the East (despite some notable exceptions). Although ethnic nationalism is widespread, until recently immigration has not been an important issue (Minkenberg 2017). Andrea Pirro (2014b: 247) points out: 'Appraising the electoral performance of these parties in terms of a native backlash against the immigrant population serves poorly as an explanation in countries where immigration does not represent a salient issue.'

However, Ivan Krastev and Stephen Holmes (2018: 126) point out that perceived fear of an influx of foreigners can be as 'real' as the actual experience of ethnic diversity in the West. They argue that 'anti-immigrant hysteria' in the face of a non-existent immigrant invasion is rooted in more realistic demographic anxieties related to the mass outmigration from the post-communist region, especially of skilled young people. Moreover, fear of ethnic diversity is created by pointing to the West as an example of how things can go wrong. To conclude, we expect that anti-immigration attitudes are most important in explaining far-right support in Europe, but that the differences between far-right voters and other citizens are greater in the West than in the East: 
Hypothesis 1a: In both post-communist and mature democracies, far-right voters have stronger anti-immigration attitudes than centre-right voters, left-wing voters and abstainers.

Hypothesis 1b: In post-communist democracies, anti-immigration attitudes have a weaker effect on electoral support for far-right parties than in mature democracies.

We focus on authoritarianism as the other main manifestation of cultural grievances (Kitschelt 1995; Rydgren 2011; Zhirkov 2014). Mudde (2007: 221) argued that authoritarianism is 'the second most important attitudinal variable' in explaining far-right voting that is related to the sociocultural dimension (after nativism). Adherence to authoritarian values reflects a belief in a strictly ordered society and protecting traditional values (Oesch 2012; Pirro 2014b). Far-right parties in both East and West promise to uphold and restore traditional sociocultural values (Golder 2016; Minkenberg 2017). Strong political leaders are assumed to secure safety for 'the people' (Kitschelt 1995; Kriesi et al. 2008).

Kris Dunn's (2015) study of five Western European countries found, however, that authoritarianism is not significantly related to far-right support. This could be due to the fact that mainstream conservative right parties also promote law and order, national unity and culturally conservative views. They have adopted some of the sociocultural issues of the far right, for instance tough policies on crime (Bale 2003; Immerzeel et al. 2015). For this reason, Immerzeel et al. (2015) claim that centre-right parties are more likely to compete electorally with far-right parties than with left-wing parties. Consequently, we refine the cultural backlash thesis: we expect that authoritarianism does not significantly distinguish between voters of conservative parties and of far-right parties, but more specifically explains why people support the far right, rather than left-wing parties or abstain.

We likewise expect that there are hardly any differences in this respect in Eastern Europe between supporters for far-right and centre-right parties. People generally more strongly endorse traditional values and oppose cultural progressiveness than in Western Europe (Kochanowitcz 2004; Krastev and Holmes 2018). Given this, mainstream right-wing parties often rally around the same law-and-order issues and we therefore similarly expect that authoritarian citizens do not necessarily vote for far-right parties, since they could also opt for centre-right parties. Hence:

Hypothesis 2: In both post-communist and mature democracies, far-right voters more strongly support authoritarianism, but only in comparison with left-wing voters and abstainers.

\section{Socioeconomic deprivation}

The second approach focuses on economic grievances. Pippa Norris and Ronald Inglehart (2019) explain far-right support through the rise of global markets, which increasingly divide the 'winners' from the 'losers'. The latter experience low employment, have lower incomes and face more economic insecurity (Kriesi 
et al. 2008). Economic and cultural explanations are, however, hard to distinguish; often a combination of the two is used to explain far-right voting. This is manifested most clearly in ethnic competition theory. According to this theory, people adopt anti-immigrant views when they perceive that they are competing with immigrants for scarce resources (Golder 2016; Lubbers et al. 2002). This is closely related to 'welfare chauvinism', the notion that only natives should benefit from welfare programmes and that foreigners should be excluded (Oesch 2008).

Matt Golder (2016: 484) points out that 'there is considerable evidence in support of the economic grievance story at the individual level'. Previous studies repeatedly showed that people who vote for far-right parties are more often from lower socioeconomic groups. They apparently feel less represented by established parties, which presumably convey the interests and preferences of the highereducated 'winners' (Bovens and Wille 2017; Kriesi et al. 2008).

However, most studies contrast far-right voters with all other voters. As already explained, we make a more detailed comparison and argue that economic deprivation accounts only explain why the electoral appeal for social democrats has declined. Kirill Zhirkov (2014) showed that far-right voters have similar characteristics to voters for left-wing parties in terms of their socioeconomic status, but differ from centre-right parties. Consequently, left-wing parties are particularly vulnerable to losing voters to the far right (Oesch 2008; Oesch and Rennwald 2018; Rydgren 2013). Moreover, those who abstain from voting are also believed to have similarly lower levels of education and a lower socioeconomic status (Allen 2017a). Hence, we expect that the widely used 'losers of globalization' argument is conditional: economic deprivation indeed demarcates far-right voters from centre-right voters, but fails to explain far-right voting if we compare far-right voters with traditional left-wing voters and abstainers.

We expect a similar pattern with regard to attitudes towards welfare policies. Herbert Kitschelt (1995) famously argued that combining free market liberalism with sociocultural authoritarianism is the 'winning formula' for far-right parties. However, scholars have argued and demonstrated that most Western European farright parties have actually blurred positions on the socioeconomic dimension (Betz 2004; Rydgren 2013), despite the fact that some of them participated in centre-right coalitions.

There is scant evidence for the influence of attitudes on income redistribution on far-right voting. Maureen Eger and Sarah Valdez (2015) found that support for income redistribution does not affect the odds of voting for far-right parties in Western Europe. Similarly, Trevor Allen (2017a) found no effect. Again, these nonfindings might be due to the fact that far-right supporters were contrasted with all other voters. Since Western European far-right parties have turned into 'a new type of working-class party', according to Oesch (2012: 48), we would only expect differences between far-right voters and centre-right voters.

We expect similar patterns in post-communist countries. Far-right parties in Eastern Europe are generally left-leaning on the economy, even more than in the West (Bustikova 2018). In terms of the supply side, the post-communist far right is thought to capitalize successfully on economic grievances surrounding welfare retrenchment (Bustikova and Kitschelt 2009). In post-communist party systems, those who are less educated - sometimes labelled as 'losers' of the transition - 
still expect (despite the collapse of communism) the state to provide extensive social welfare (Allen 2017b; Polyakova 2015). We hence expect that in terms of socioeconomic background and attitudes to redistribution, we will observe a similar overlap between far-right voters and left-wing voters and abstainers as in Western Europe, and only pronounced differences between centre-right and farright supporters. Therefore:

Hypothesis 3: In both mature and post-communist democracies, far-right voters belong to lower socioeconomic status groups, but only when compared with centre-right voters.

Hypothesis 4: In both mature and post-communist democracies, far-right voters are more strongly in favour of income redistribution, but only when compared with centre-right voters.

\section{Political disillusionment: protest voting}

Protest vote explanations imply that cynicism and discontent with politics motivate people to vote for far-right parties (Dalton and Weldon 2005; Rooduijn 2017; Van der Brug et al. 2000). As Grigore Pop-Eleches (2010: 223) puts it: 'Protest voting is the practice of voting for a party not because of the actual content of its electoral message but in order to "punish" other parties.' Empirical evidence from Western Europe shows that individuals who are dissatisfied with politics vote for far-right parties as a token of protest (Norris 2005). Similarly, it is argued that low political trust facilitated populist parties in post-communist countries to attract substantial electoral support (Algan et al. 2017). Distrust could have different underlying reasons. Conrad Ziller and Thomas Schübel (2015), for instance, find that exposure to corruption diminishes political trust, which in turn leads to a greater propensity to vote for far-right parties.

Declining political trust has not only been observed at the national level, but also at the supranational level (Harteveld et al. 2013; Hay 2013). The latter is, for instance, conceptualized as trust in the United Nations and European Parliament, which has possibly different effects on far-right voting compared with trust in national institutions. Regarding the supply side, far-right parties indeed have eurosceptic attitudes; they are against European economic collaboration and cultural integration (Pirro 2014b; Werts et al. 2012). Han Werts et al. (2012) show that euroscepticism is an important explanation for far-right voting, and, moreover, that the effect is comparable in East and West.

Furthermore, studies show mixed results when comparing the degree of political trust between far-right voters and abstainers. For example, Russell Dalton and Steven Weldon (2005) show that abstainers have lower levels of political trust than far-right voters, whereas other studies revealed no differences in levels of political trust between non-voters and far-right voters (Allen 2017a; Zhirkov 2014).

After political trust, political efficacy explains why people vote and which party they choose (Pateman 1970; Verba et al. 1995). It defines how individuals perceive the responsiveness of politicians, and whether the political system provides a place for the individual to contribute (Niemi et al. 1991; Schneider et al. 2014). As with 
the influence of political distrust, voters for far-right parties have a stronger feeling that their voice is not heard and that political elites ignore 'ordinary citizens', compared with voters of other parties (Rooduijn et al. 2016). ${ }^{3}$

We expect similar associations between political trust and external efficacy and far-right voting in both the West and the East. People in post-communist societies inherited generally low levels of political trust from the communist past. Political trust was further undermined by the weakness of the institutions in shaping the transition to democracies (Howard 2003; Szelenyi and Wilk 2010). Similarly, the feeling that one can influence political outcomes - external efficacy - of postcommunist citizens is also generally rather weak (Mierina 2011). Consequently, populist rhetoric has not been adopted exclusively by right-wing parties; left-wing and centre parties also frequently campaigned on anti-corruption issues and dissatisfaction with political elites (Hanley and Sikk 2016). Nevertheless, since nativism is often bundled together with sentiments against the political elites 'that sold national interests to outsiders, foreigners and ethnic minorities' (Bustikova 2018: 571), we expect that anti-elitism is predominantly associated with far-right voting. Thus, we formulate the following hypotheses:

Hypothesis 5: In both mature and post-communist democracies, voters for far-right parties have less trust in national and supranational political institutions than centre-right and left-wing voters do. However, they do not differ from those who abstain.

Hypothesis 6: In both mature and post-communist democracies, voters for far-right parties have lower levels of external political efficacy than centre-right and left-wing voters. However, they do not differ from those who abstain.

To conclude, an overview of our hypotheses is provided in Table 1.

\section{Research design \\ Data and case selection}

This study uses ESS data for 2014 and 2016 (rounds 7 and 8). As already explained, we investigate whether Western European far-right electorates are similar to their counterparts in post-communist Europe, or whether electoral support for this party family requires a region-specific explanation. ${ }^{4}$ The Western European democracies in our sample are: Austria, Belgium, Denmark, Finland, France, Germany, ${ }^{5}$ the Netherlands, Norway, the UK, Sweden and Switzerland. We include the following post-communist democracies: Czech Republic, Estonia, Hungary, Lithuania, Poland and Slovenia. Except for Denmark, all countries participated in both ESS waves. We decided to use only the two most recent waves of ESS data (i.e. 2014 and 2016) because we focus on contemporary Europe. Extending the period under study would add a temporal dimension and thus require an additional comparative perspective; the importance of the three explanations (economic deprivation, cultural conflict and political disillusionment) could have changed over time. 
Table 1. Overview of our Hypotheses

\begin{tabular}{|c|c|c|c|}
\hline \multirow[b]{2}{*}{ Are far-right voters ... } & \multicolumn{3}{|c|}{ Compared with ... } \\
\hline & $\begin{array}{l}\text { Centre-right } \\
\text { voters }\end{array}$ & $\begin{array}{c}\text { Traditional left } \\
\text { voters }\end{array}$ & Non-voters \\
\hline more anti-immigrant? ( $\mathrm{H} 1 \mathrm{a})$ & Yes $^{\star}$ & Yes* & Yes* \\
\hline more authoritarian? $(\mathrm{H} 2)$ & No & Yes & Yes \\
\hline more socioeconomically deprived? (H3) & Yes & No & No \\
\hline more in favour of redistribution? $(\mathrm{H} 4)$ & Yes & No & No \\
\hline more politically distrustful? (H5) & Yes & Yes & No \\
\hline less externally efficacious? (H6) & Yes & Yes & No \\
\hline
\end{tabular}

Note: ${ }^{\star}$ Yes, and interaction effect: the differences are smaller in East than in West $(\mathrm{H} 1 \mathrm{~b})$.

\section{Dependent variable}

Following Zhirkov (2014), we distinguish four groups of respondents. First, respondents are grouped into those who participated in the last national elections and those who abstained. Respondents who were not eligible to vote are excluded from the analysis. Subsequently, voters are grouped into three categories: far right, centre right (including Christian democrats and conservatives, see online Appendix A), and traditional left-wing (including socialists and social democrats, see online Appendix B). Our operationalization of party families is based on Immerzeel et al. (2015).

Furthermore, we excluded respondents who voted for parties that were difficult to classify (see Oesch and Rennwald 2018). We excluded the new left parties (such as Green parties) from the old left-wing party family, since they differ in some fundamental respects: they are exceptionally popular among sociocultural professionals and do not fare well among the working class, whereas social democratic parties are the most popular among production and service workers (Oesch and Rennwald 2018). ${ }^{6}$

Table 2 shows the parties we denote as far right. This study updates the selection of Immerzeel et al. (2015). Most importantly, we include Law and Justice (PiS) and Fidesz. Although both parties were often considered to be conservative right-wing parties, scholars increasingly define them as 'radicalized parties' (Bustikova 2018). For instance, Michael Minkenberg (2017: 124) describes them as 'right-wing populist with programmatic elements of radical right'. We similarly argue that they have transformed from conservative right to far right (see Gómez-Reino and Llamazares 2013; Stanley 2017).

We used the Chapel Hill Expert Survey (CHES) from 2014 (Bakker et al. 2014) to cross-validate our far-right classification. Following Norris and Inglehart (2019: 233), we constructed an authoritarian-libertarian scale consisting of seven items (galtan, nationalism, civlib_law and order, multiculturalism, social lifestyle, immigration policy, ethnic minorities) that indicate parties' positions on sociocultural 
Table 2. Far-Right Parties of the 16 Investigated Countries

\begin{tabular}{|c|c|c|c|c|c|c|c|c|}
\hline Country & Parties & Parties (EN) & Abbreviation & $\begin{array}{l}\text { Vote } \\
\text { (ESS 2014) }\end{array}$ & $\begin{array}{c}\text { Vote } \\
\text { (ESS 2016) }\end{array}$ & $\begin{array}{l}\text { Position } \\
\text { score } \\
\text { (CHES } \\
\text { 2014) }\end{array}$ & $\begin{array}{r}\text { Main issue } \\
\text { (CHES 2014) }\end{array}$ & $\begin{array}{l}\text { Second issue } \\
\text { (CHES 2014) }\end{array}$ \\
\hline \multirow[t]{2}{*}{ Austria } & $\begin{array}{l}\text { Freiheitliche Partei } \\
\text { Österreichs }\end{array}$ & $\begin{array}{l}\text { Freedom Party of } \\
\text { Austria }\end{array}$ & FPÖ & $14.0 \%$ & $18.5 \%$ & 9.2 & immigration & anti-elite rhetoric \\
\hline & Bündnis Zukunft Österreich & $\begin{array}{l}\text { Alliance for the } \\
\text { Future of Austria }\end{array}$ & BZÖ & $1.2 \%$ & $0.7 \%$ & 7.8 & $\begin{array}{l}\text { public services vs } \\
\text { taxes }\end{array}$ & anti-elite rhetoric \\
\hline \multirow[t]{2}{*}{ Belgium } & $\begin{array}{l}\text { Vlaams Blok/Belang } \\
\text { (Flanders) }\end{array}$ & Flemish Interest & VB & $2.1 \%$ & $2.4 \%$ & 9.2 & immigration & $\begin{array}{l}\text { tie: multiculturalism } \\
\text { and nationalism }\end{array}$ \\
\hline & Front National & National Front & FN & $0.3 \%$ & $0.2 \%$ & $\mathrm{~N} / \mathrm{A}$ & $\mathrm{N} / \mathrm{A}$ & N/A \\
\hline $\begin{array}{l}\text { Czech } \\
\text { Republic }\end{array}$ & $\begin{array}{l}\text { Úsvit př́mé demokracie } \\
\text { Tomia }\end{array}$ & $\begin{array}{l}\text { Dawn of Direct } \\
\text { Democracy }\end{array}$ & Úsvit & $3.9 \%$ & $3.3 \%$ & 8.9 & anti-elite rhetoric & immigration \\
\hline Denmark & Dansk folkeparti & $\begin{array}{l}\text { Danish People's } \\
\text { Party }\end{array}$ & DFP & $12.1 \%$ & $\mathrm{~N} / \mathrm{A}$ & 8.5 & immigration & $\begin{array}{l}\text { public services vs } \\
\text { taxes }\end{array}$ \\
\hline Estonia & $\begin{array}{l}\text { Eesti Konservatiivne } \\
\text { Rahvaerakond }\end{array}$ & $\begin{array}{l}\text { Conservative } \\
\text { People's Party } \\
\text { of Estonia }\end{array}$ & EKRE & $1.0 \%$ & $6.0 \%$ & $\mathrm{~N} / \mathrm{A}$ & N/A & $\mathrm{N} / \mathrm{A}$ \\
\hline Finland & Perussuomalaiset & $\begin{array}{l}\text { Finns' Party/True } \\
\text { Finns }\end{array}$ & PS & $13.9 \%$ & $14.3 \%$ & 9.1 & anti-elite rhetoric & EU integration \\
\hline France & Front National & National Front & FN & $11.9 \%$ & $13.4 \%$ & 9.2 & immigration & multiculturalism \\
\hline \multirow[t]{2}{*}{ Germany } & Alternative Für Deutschland & $\begin{array}{l}\text { Alternative for } \\
\text { Germany }\end{array}$ & AfD & $3.3 \%$ & $2.8 \%$ & 8.8 & EU integration & immigration \\
\hline & $\begin{array}{l}\text { Nationaldemokratische } \\
\text { Partei Deutschlands }\end{array}$ & $\begin{array}{l}\text { National } \\
\text { Democratic } \\
\text { Party of } \\
\text { Germany }\end{array}$ & NPD & $0.5 \%$ & $0.4 \%$ & 9.7 & nationalism & immigration \\
\hline \multirow[t]{2}{*}{ Hungary } & $\begin{array}{l}\text { Fidesz - Magyar Polgári } \\
\text { Szövetség }\end{array}$ & $\begin{array}{l}\text { Hungarian Civic } \\
\text { Alliance }\end{array}$ & Fidesz & $48.7 \%$ & $66.6 \%$ & 8.2 & nationalism & state intervention \\
\hline & $\begin{array}{l}\text { Jobbik - Magyar országért } \\
\text { Mozgalom }\end{array}$ & $\begin{array}{l}\text { Movement for a } \\
\text { Better Hungary }\end{array}$ & Jobbik & $18.6 \%$ & $11.5 \%$ & 9.5 & nationalism & anti-elite rhetoric \\
\hline
\end{tabular}


Table 2. (Continued.)

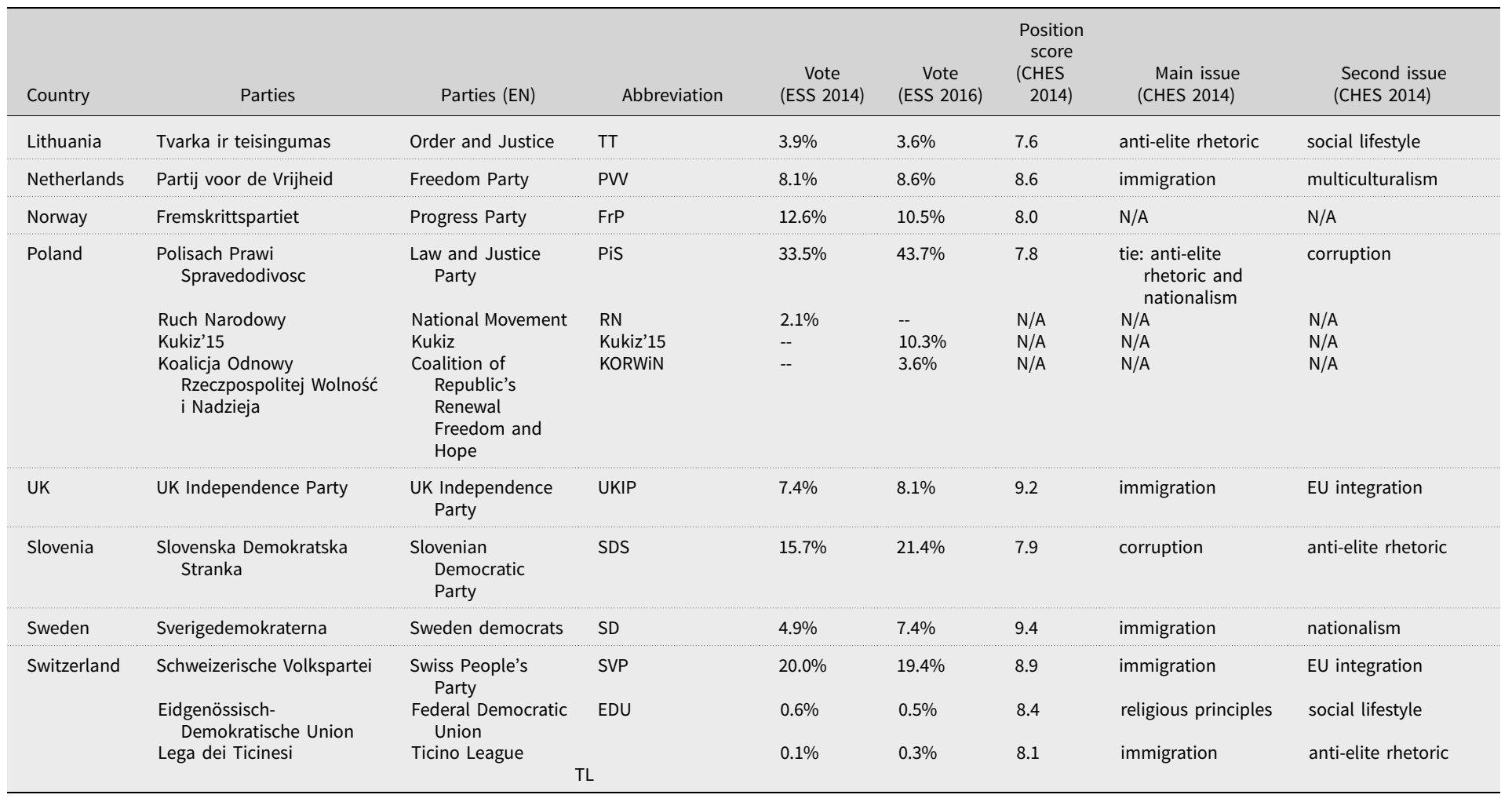


issues (Cronbach's $\alpha=0.97 ; \mathrm{N}$ parties $=267$ ). These measures include whether parties favour traditional social values, promote nationalism and restrict immigration and are measured on a scale from 0 (libertarian-cosmopolitan) to 10 (authoritarian-nativist). Table 2 shows that all the far-right parties we included score 7.5 or higher on this scale.

Not all parties that score 7.5 or higher are included in our selection, because issue salience also matters. According to Tjitske Akkerman et al. (2016), among others, the label 'radical' not only refers to an extreme position, but also implies salience. Hence, we examined the two most important issues of the party in question, according to the CHES (see Table 2). Issue salience clarifies why a few parties with a score of 7.5 or higher are nevertheless usually not considered as far-right parties, such as the orthodox Christian Political Reformed Party (8.6) in the Netherlands - its two main issues are 'religious principles' and 'public services vs taxes'. For the same reason, parties such as the German Christian Democratic Union (7.4) and French Union for a Popular Movement (7.4) are distinguished from the far right, although they score relatively high on the sociocultural dimension: they neither stress authoritarian-nativist issues, nor anti-elitism. In contrast, Table 2 shows that all our selected parties have a strong authoritarian-nativist position (7.5 or higher) and deem anti-elitism and/or authoritarian-nativist issues to be important. $^{\text {? }}$

Finally, we should point out that only adopting anti-elite rhetoric is not sufficient for a party to be labelled 'far right'. For instance, we did not include ANO (Action of Dissatisfied Citizens), established by the Czech businessman Andrej Babiš. The party is centrist anti-establishment/populist rather than far right (Hanley and Sikk 2016; Van Kessel 2015). We therefore classify it as centre right (its authoritarian-nativist score is 4.8). Our collection of traditional left-wing parties also includes some 'anti-establishment' parties, such as Die Linke in Germany (Rooduijn 2017).

Table 3 shows the distribution of the four groups. It shows that in postcommunist countries, non-voters form the largest group (39.1\%) of respondents, whereas voters for centre-right parties constitute the largest group in Western Europe $(41.6 \%)$. In our sample, the share of far-right voters is substantially higher in CEE (15.7\%) than in Western Europe (8.6\%).

\section{Explanatory variables}

All details on the measurements of the variables, including question wordings and answer categories, are presented in online Appendix C. The descriptive statistics and reliability coefficients (Cronbach's $\alpha$ ) are depicted in online Appendix D.

\section{Cultural backlash}

First, anti-immigration attitudes is a scale consisting of three questions. The questions ask if immigrants are 'good or bad for the economy', 'undermining or enriching cultural life' and 'make the country a better or worse place to live in'. The answer categories run from 0 to 10 . A higher score represents stronger antiimmigration attitudes. Following, among others, Norris and Inglehart (2019) and Werts et al. (2012), citizens' adherence to authoritarian values is operationalized 
Table 3. Respondents' Distribution per Group

\begin{tabular}{|c|c|c|c|c|}
\hline & \multicolumn{2}{|c|}{ Mature democracies } & \multicolumn{2}{|c|}{$\begin{array}{l}\text { Post-communist } \\
\text { democracies }\end{array}$} \\
\hline & $\mathrm{N}$ & $\%$ & N & $\%$ \\
\hline Far right & 2,452 & 8.6 & 2,289 & 15.7 \\
\hline Centre right & 11,848 & 41.6 & 4,374 & 30.1 \\
\hline Left-wing & 8,329 & 29.2 & 2,206 & 15.2 \\
\hline Non-voters & 5,888 & 20.7 & 5,684 & 39.1 \\
\hline Total & 28,517 & 100.0 & 14,553 & 100.0 \\
\hline
\end{tabular}

Source: ESS (2014-16).

by four questions about topics concerning law and order. Respondents were, for instance, asked to what extent the government needs to ensure safety against threats and whether traditions are important.

\section{Socioeconomic status}

Three variables are used. First, respondents' perceived adequacy of income is asked, which measures the capacity to live with one's current income. Answers ranged from 'very difficult' (1) to 'living very comfortable on present income' (4). Unfortunately, although it would be preferable to have an indicator of objective financial deprivation in addition to subjective deprivation, the number of missing cases of the income variable is rather large. Both dimensions could indeed differently affect voting behaviour. Nevertheless, both in mature democracies and in post-communist democracies the income decile correlates with the perceived income $(r=0.47 / 0.49, p<0.01)$. Second, educational level is measured using the International Standard Classification of Education, which ranges from 1 to 7. Third, unemployment is used as proxy of socioeconomic deprivation (Allen 2017b; Kitschelt 1995). Furthermore, respondents' support for income redistribution is measured with the item 'government should reduce differences in income'. The answer categories range from 'disagree strongly' (1) to 'strongly agree' (5).

\section{Protest voting}

First, national political trust is operationalized by five questions regarding trust in national political institutions, such as the parliament and legal system. The scale ranges from 0 ('no trust') to 10 ('complete trust'). Supranational political trust measures trust in the European Parliament and the United Nations (two questions). Next, the measurement of external political efficacy also consists of two items. An example of a question is: 'How much would you say that politicians care what people like you think?? ${ }^{8}$ Finally, we included two sociodemographic factors as control variables, namely, age and gender.

As we explained earlier, it is difficult to draw strict distinctions between cultural, economic and political grievances. The correlation matrix (see online Appendix E) shows how they are related. As one would expect based on existing studies (Mayda 
2006), cultural backlash is associated with socioeconomic deprivation. People with lower perceived incomes have stronger anti-immigration attitudes, in both mature $(r=-0.20)$ and post-communist democracies $(r=-0.17)$. Education level has a similar negative relationship.

Furthermore, we find a negative relationship between socioeconomic status and political disillusionment: the higher one's perceived income and education level, the more favourable one's opinions about politics. Finally, the strongest associations exist between the indicators of political and cultural grievances, especially in Western Europe. For instance, the more negative one's attitudes towards immigrants, the less trust one has in national and supranational politics (mature democracies: $r=-0.43 /-0.40$; post-communist democracies: $r=-0.17 /-0.25$ ).

\section{Findings}

We conducted multilevel multinomial logistic regressions, with the four different groups as the dependent variable: far-right voters, traditional left-wing voters, centre-right voters and abstainers. ${ }^{9}$ The results are presented in Table 4 (mature democracies) and Table 5 (post-communist democracies). ${ }^{10}$ We show both the estimates and changes in predicted probabilities. Far-right voters are the reference category. A negative estimate thus indicates a higher score on the respective variable: the more likely it is that one votes for the far right, rather than respectively for a centre-right party, a traditional left-wing party, or abstains from voting. The change in the predicted probability is calculated when the respective independent variable changes from the lowest to the highest value $(\min / \max ) .{ }^{11}$ For instance, Western Europeans who live very comfortably on their present income have a 10 percentage points higher likelihood of voting for the centre right than for the far right than people who find it very difficult to live on their current income.

Our results are summarized in Table 6. The first finding stands out: as expected, anti-immigration attitudes are consistently related to electoral support for the far right (support for H1a), unlike other explanatory factors. They most importantly account for differences between far-right voters and the other three groups of citizens. In Western Europe, the likelihood differences range from 48 percentage points (compared with centre-right voters) to 68 percentage points (compared with left-wing voters).

The impact of anti-immigration attitudes is less pronounced in post-communist democracies (tentative support for $\mathrm{H} 1 \mathrm{~b}$ ). If we contrast people with the most positive and most negative attitudes towards immigration, the predicted probability of far-right voting decreases by 22 percentage points (compared with abstaining), 34 percentage points (compared with voting for left-wing parties) and 37 percentage points (compared with voting for the centre right), which are weaker effects than we observed in mature democracies. We will return to a formal test of the moderation effect of region ( $\mathrm{H} 1 \mathrm{~b})$ later.

Our authoritarian hypothesis $(\mathrm{H} 2)$ is also supported for both mature and post-communist democracies, due to the observed similarities between far-right voters and centre-right voters in their adherence to authoritarian values. In contrast, far-right voters are indeed significantly more authoritarian when we compare them with abstainers and left-wing voters. These results confirm 
Table 4. Multilevel Multinomial Logistic Regression: Mature Democracies

\begin{tabular}{|c|c|c|c|c|c|c|}
\hline Variables (range) & \multicolumn{6}{|c|}{ Mature democracies } \\
\hline \multicolumn{7}{|l|}{ Cultural backlash } \\
\hline Anti-immigration attitudes $(0-10)$ & $-0.31(0.01)$ & -0.48 & $-0.46(0.01)$ & -0.68 & $-0.29(0.01)$ & -0.58 \\
\hline \multicolumn{7}{|l|}{ Threatened socioeconomic status } \\
\hline Perceived income (1-4) & $0.20(0.04)$ & 0.10 & $-0.05(0.04)$ & -0.02 & $-0.22(0.04)$ & -0.13 \\
\hline Education (1-7) & $0.17(0.02)$ & 0.14 & $0.08(0.02)$ & 0.06 & $-0.09(0.02)$ & -0.11 \\
\hline Unemployment (0-1) & $-0.47(0.12)$ & -0.08 & $-0.10(0.12)$ & -0.01 & $0.07(0.11)$ & 0.02 \\
\hline Income distribution (1-5) & $-0.18(0.02)$ & -0.10 & $0.37(0.03)$ & 0.25 & $0.03(0.02)$ & 0.03 \\
\hline External political efficacy $(0-10)$ & $0.18(0.04)$ & 0.10 & $0.16(0.04)$ & 0.09 & $-0.13(0.04)$ & -0.11 \\
\hline \multicolumn{7}{|l|}{ Control variables } \\
\hline Age $(18-102)$ & $0.02(0.00)$ & 0.19 & $0.02(0.00)$ & 0.16 & $-0.02(0.00)$ & -0.41 \\
\hline Female (0-1) & $0.40(0.05)$ & 0.05 & $0.43(0.05)$ & 0.06 & $0.42(0.05)$ & 0.09 \\
\hline Log-likelihood & -31068.89 & & & & & \\
\hline$N=$ & 28,517 & & & & & \\
\hline
\end{tabular}


Table 5. Multilevel Multinomial Logistic Regression: Post-Communist Democracies

\begin{tabular}{|c|c|c|c|c|c|c|}
\hline \multirow[b]{3}{*}{ Variables (range) } & \multicolumn{6}{|c|}{ Post-communist democracies } \\
\hline & \multicolumn{2}{|c|}{ Centre-right } & \multicolumn{2}{|c|}{ Left-wing } & \multicolumn{2}{|c|}{ Non-voters } \\
\hline & $\begin{array}{l}\text { Estimate } \\
\text { (S.E.) }\end{array}$ & $\begin{array}{l}\text { Probability } \\
\mathrm{min} / \mathrm{max}\end{array}$ & $\begin{array}{l}\text { Estimate } \\
\text { (S.E.) }\end{array}$ & $\begin{array}{l}\text { Probability } \\
\min / \max \end{array}$ & $\begin{array}{l}\text { Estimate } \\
\text { (S.E.) }\end{array}$ & $\begin{array}{c}\text { Probability } \\
\min / \max \end{array}$ \\
\hline \multicolumn{7}{|l|}{ Cultural backlash } \\
\hline Anti-immigration attitudes $(0-10)$ & $-0.22(0.02)$ & -0.37 & $-0.15(0.02)$ & -0.34 & $-0.15(0.02)$ & -0.22 \\
\hline Authoritarian values (1-6) & $-0.07(0.04)$ & -0.06 & $-0.19(0.04)$ & -0.21 & $-0.28(0.04)$ & -0.19 \\
\hline \multicolumn{7}{|l|}{ Threatened socioeconomic status } \\
\hline Perceived income (1-4) & $0.21(0.05)$ & 0.12 & $0.06(0.05)$ & 0.04 & $-0.09(0.05)$ & -0.04 \\
\hline Education (1-7) & $0.13(0.02)$ & 0.14 & $0.10(0.02)$ & 0.14 & $-0.16(0.02)$ & -0.15 \\
\hline Unemployment $(0-1)$ & $0.08(0.16)$ & 0.01 & $0.06(0.18)$ & 0.01 & $0.23(0.14)$ & 0.03 \\
\hline Income distribution (1-5) & $-0.16(0.03)$ & -0.11 & $0.10(0.04)$ & 0.10 & $0.02(0.03)$ & 0.01 \\
\hline \multicolumn{7}{|l|}{ Protest vote } \\
\hline National political trust $(0-10)$ & $-0.20(0.02)$ & -0.38 & $-0.23(0.02)$ & -0.50 & $-0.35(0.02)$ & -0.60 \\
\hline Supranational political trust $(0-10)$ & $0.10(0.02)$ & 0.17 & $0.15(0.02)$ & 0.34 & $0.13(0.02)$ & 0.19 \\
\hline External political efficacy $(0-10)$ & $0.00(0.04)$ & 0.01 & $-0.01(0.04)$ & -0.01 & $-0.30(0.04)$ & -0.22 \\
\hline \multicolumn{7}{|l|}{ Control variables } \\
\hline Age (18-92) & $0.01(0.00)$ & 0.19 & $0.03(0.00)$ & 0.43 & $-0.02(0.00)$ & -0.21 \\
\hline Female $(0-1)$ & $0.25(0.06)$ & 0.05 & $0.20(0.07)$ & 0.05 & $0.33(0.06)$ & 0.05 \\
\hline Log-likelihood & -15795.55 & & & & & \\
\hline$N=$ & 14,553 & & & & & \\
\hline
\end{tabular}


Table 6. Summary of our Findings

\begin{tabular}{|c|c|c|c|}
\hline \multirow[b]{2}{*}{ Are far-right voters ... } & \multicolumn{3}{|c|}{ Compared with ... } \\
\hline & $\begin{array}{l}\text { Centre-right } \\
\text { voters }\end{array}$ & $\begin{array}{l}\text { Traditional left } \\
\text { voters }\end{array}$ & Non-voters \\
\hline more anti-immigrant? (H1a) & Yes & Yes & Yes \\
\hline more authoritarian? $(\mathrm{H} 2)$ & No & Yes & Yes \\
\hline $\begin{array}{l}\text { more socioeconomically } \\
\text { deprived? (H3) }\end{array}$ & -- & -- & -- \\
\hline - have lower perceived income? & Yes & No & $\mathrm{No}^{\star}$ \\
\hline - have lower education level? & Yes & Yes & $\mathrm{No}^{*}$ \\
\hline - are more often unemployed? & $\begin{array}{l}\text { West: Yes } \\
\text { East: No }\end{array}$ & No & No \\
\hline $\begin{array}{l}\text { more in favour of redistribution? } \\
(\mathrm{H} 4)\end{array}$ & Yes & No* $^{*}$ & No \\
\hline more politically distrustful? (H5) & -- & -- & -- \\
\hline - towards national politics? & $\begin{array}{l}\text { West: Yes } \\
\text { East: } \mathrm{No}^{\star \star}\end{array}$ & $\begin{array}{l}\text { West: Yes } \\
\text { East: No** }\end{array}$ & No* \\
\hline - towards supra-national politics? & Yes & Yes & Yes \\
\hline less externally efficacious? (H6) & $\begin{array}{l}\text { West: Yes } \\
\text { East: No }\end{array}$ & $\begin{array}{l}\text { West: Yes } \\
\text { East: No }\end{array}$ & $\mathrm{No}^{*}$ \\
\hline
\end{tabular}

Notes: Bold means in line with our hypothesis.

*There is a significant effect in the opposite direction (we expected 'No').

${ }^{\star *}$ There is a significant effect in the opposite direction than expected (we expected 'Yes').

Dunn's (2015) conclusion that authoritarianism is not a consistent predictor of farright support.

Next, the socioeconomic deprivation hypothesis (H3) is largely confirmed. In Western Europe, far-right voters have a lower perceived income, are more often unemployed and are lower educated than the centre-right voters. In postcommunist democracies far-right voters are likewise less educated and have lower perceived incomes than centre-right voters. Unemployment is not linked with far-right voting in Eastern European democracies.

As we expected, our results demonstrate that in both mature and postcommunist democracies far-right voters are not socioeconomic 'losers' if we compare them with traditional left-wing voters and abstainers. In both country-sets, perceived income ranks the far-right voters with the left-wing voters, in line with Oesch (2008). Furthermore, far-right voters are not more often unemployed than abstainers and left-wing voters. The only minor deviation from our socioeconomic deprivation hypothesis is that far-right voters are lower educated than left-wing voters. 
If any group stands out as the socioeconomic underclass, it is the abstainers. In both regions, they are less educated and have lower perceived incomes than farright voters. The likelihood of voting for the far right (rather than abstain) is about 13 (Western Europe) and 4 (CEE) percentage points higher for people who report they are able to live comfortably on their current income compared with those who consider this very difficult.

Next, in line with our income redistribution hypothesis (H4), far-right voters in both regions more strongly support income redistribution than centre-right voters. Moreover, as we expected, abstainers do not differ significantly from far-right voters, which contradicts Allen's (2017a) findings (he studied mature democracies). In contrast to our expectation, far-right voters in both regions differ significantly from left-wing voters: they oppose income redistribution more strongly. Thus, overall, far-right voters are neither economically right nor left.

We finally evaluate the third approach - protest voting - to explain far-right support. Our expectations are corroborated in Western European democracies: far-right voters have less trust in national political institutions (H5) and perceive less external efficacy (H6) compared with centre-right and left-wing voters. Moreover, abstainers have low levels of political trust similar to far-right voters. This finding resembles Zhirkov's (2014) results, but contradicts Dalton and Weldon (2005). Likewise, farright supporters and non-voters in Western Europe think that politicians are unresponsive to the demands of citizens to the same degree. This corresponds with findings of Eefje Steenvoorden and Eelco Harteveld (2018).

As we expected, distrust of politics is likewise important at the supranational level. Indeed, Western European far-right voters have less trust in supranational institutions (Werts et al. 2012), not only compared with centre-right voters and left-wing voters, but also in comparison with the abstainers.

Shifting our focus to post-communist democracies, we surprisingly find that farright voters have more trust in national politics when compared with all other groups (rejecting $\mathrm{H} 5$ ). We will come back to this remarkable finding later. Far-right voters in CEE also perceive significantly higher levels of external efficacy than abstainers and left-wing voters (rejecting H6). In fact, some effects seem rather strong. The likelihood of voting for the far right, rather than for left-wing parties, is about 50 percentage points higher for those who have most trust in national politics than for those who are most distrustful; compared with centre-right voters, this difference is 38 percentage points.

To sum up, our results show that discontent with politics in post-communist democracies is not only, and not predominantly, rooted in far-right voters, but is also rooted in other voters and particularly the abstainers. Interestingly, however, we observe the opposite pattern when considering trust in supranational governance: like their counterparts in Western Europe, CEE far-right voters are more distrustful of the EU and UN, compared with all other groups. The findings supports Lenka Bustikova's (2018) claim that eurosceptic attitudes bridge East-West differences among the far right.

Finally, let us return to the only variable that - together with distrust in supranational government - consistently relates to far-right voting: anti-immigrant attitudes. We ran an additional regression model with all countries pooled together in which we included an interaction term in addition to all independent variables 
(results are shown in online Appendix F). The results show that the effects of antiimmigrant attitudes on far-right voting are indeed significantly stronger in the West than in the East, thus supporting H1b. This finding confirms Allen (2017b).

To assess whether particular countries drive these results, we show the country-by-country results in Figure 1. They reassert that the effects of antiimmigration attitudes are generally weaker in the post-communist countries. A notable exception is Estonia, where anti-immigration feelings are relatively strong determinants of support for the EKRE (but see Trumm 2018). At the other end, the case of Lithuania reveals insignificant effects - apparently, it is rather hard to predict support for Order and Justice (TT), since most other predictors are also irrelevant. These findings indeed relate to the supply-side issue of party classification: one would expect weaker effects in countries where far-right parties do not have an openly nativist agenda and where mainstream parties are less reluctant to adopt far-right themes and are tough on immigration (Bale 2003). Finally, it is important to note that our conclusion of weaker effects does not imply that the level of anti-immigration attitudes is lower in the East than in the West - in fact, the opposite is true (see online Appendix D).

Finally, Figure 2 summarizes the different impacts of anti-immigrant attitudes on far-right voting in Western and Eastern Europe. It shows that among those who have the most positive attitudes towards immigrants, hardly anyone in Western Europe votes for the far right; by contrast, the predicted probability in post-communist countries is about $17 \%$. For people with the strongest antiimmigrant attitudes, the predicted probability of voting for the far right is about 35\% (Western Europe) and 26\% (Eastern Europe). The contrast is thus much more pronounced in Western Europe.

It is interesting to note that in Western Europe the probability that one votes for a left-wing party dramatically decreases if anti-immigrant sentiments increase, whereas in post-communist democracies the probability of voting for left-wing parties hardly changes. In contrast, if we consider centre-right parties, our results show that anti-immigrant attitudes substantially reduce the likelihood of voting for these parties in CEE. In Western Europe, however, there is barely any difference in the probability of voting for a centre-right party if we compare people with the strongest and weakest anti-immigration attitudes.

\section{Robustness checks}

To assess the robustness of our findings, we have conducted several robustness checks. These checks can be found in online Appendix G. Here, we briefly outline the main outcomes.

First, we assessed how the results would differ if we used the standard technique of comparing far-right voters with the rest of the electorate. This reveals that the important nuances we highlighted are obfuscated in a conventional design. For instance, it shows that far-right voters have significantly stronger authoritarian sentiments, whereas our analysis revealed that this is not true if we compare them with centre-right voters. Another example is that the conventional design shows that farright voters are less educated than the rest of the electorate, whereas we concluded that this is incorrect if we compare them with non-voters. 


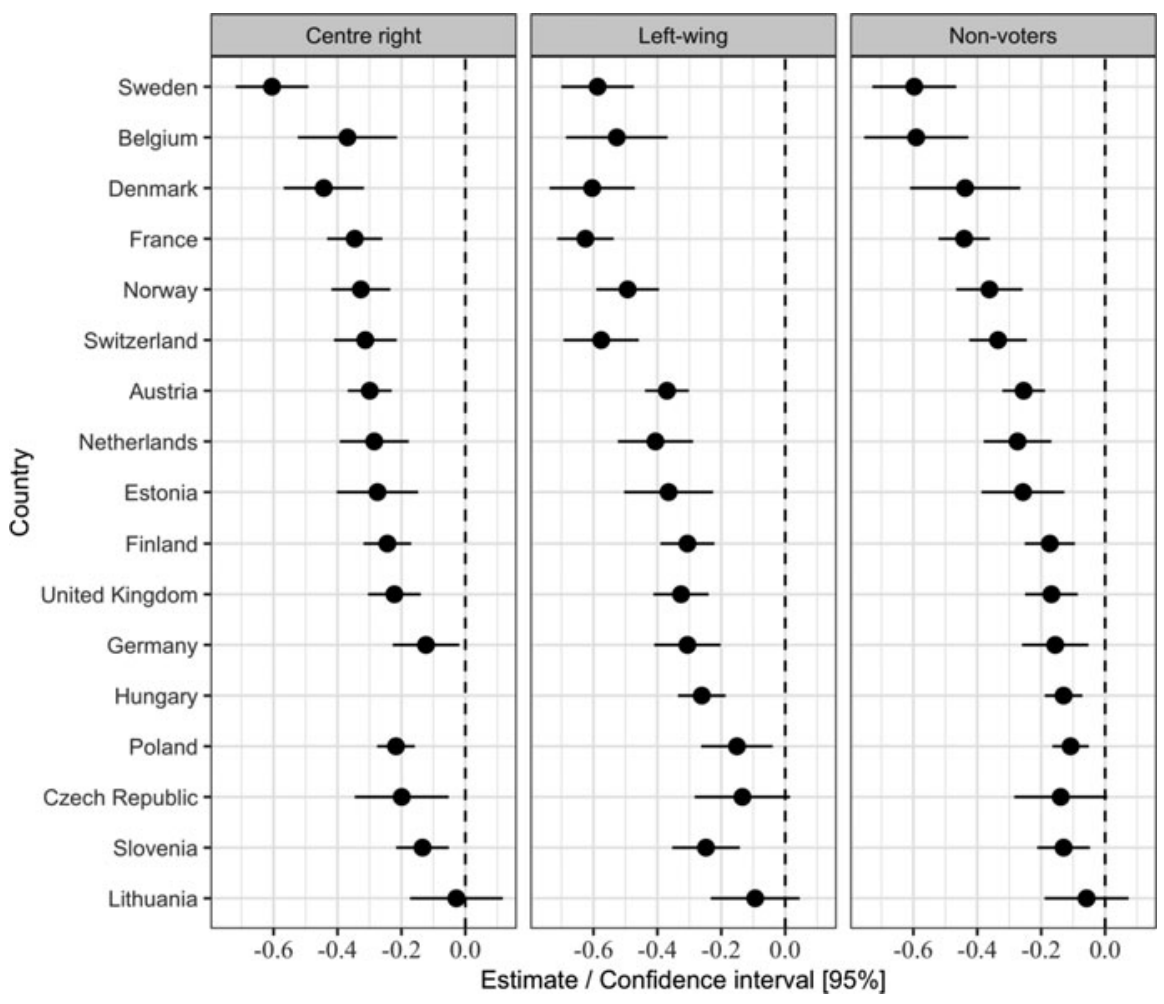

Figure 1. Country-by-Country Analysis of the Effect of Anti-Immigrant Attitudes: Far-right voters are the reference category

Second, to what extent are results influenced by the classification of parties and the inclusion or exclusion of countries? Since they are popular among a large portion of the population, PiS (Poland) and Fidesz (Hungary) are particularly important cases to consider. If we classify both parties as centre right, instead of far right, this leads to substantially different results with regard to the effect of trust in national politics: we find that in post-communist democracies far-right voters have less trust in national politics when compared with centre-right voters and left-wing voters (in line with H5). They are still more trustful than non-voters, although this difference becomes much smaller.

Our falsification of $\mathrm{H} 5$ for post-communist countries - far-right voters in CEE were more trustful - thus depends on the fact that we classified PiS and Fidesz as part of the far-right family. It is important to note that three parties we classified as far right were in power at the time of the surveys, namely PiS in Poland (since 2015), Fidesz in Hungary (since 2014) and Order and Justice in Lithuania (2012-16). Appendix G includes a country-by-country analysis of the effect of trust in national politics. Our robustness check suggests that the 'protest voting' explanation is context-dependent: when far-right parties are in government, their supporters are not politically dissatisfied, or at least not more so than voters of other parties. Two underlying mechanisms could be at work here: far-right voters 


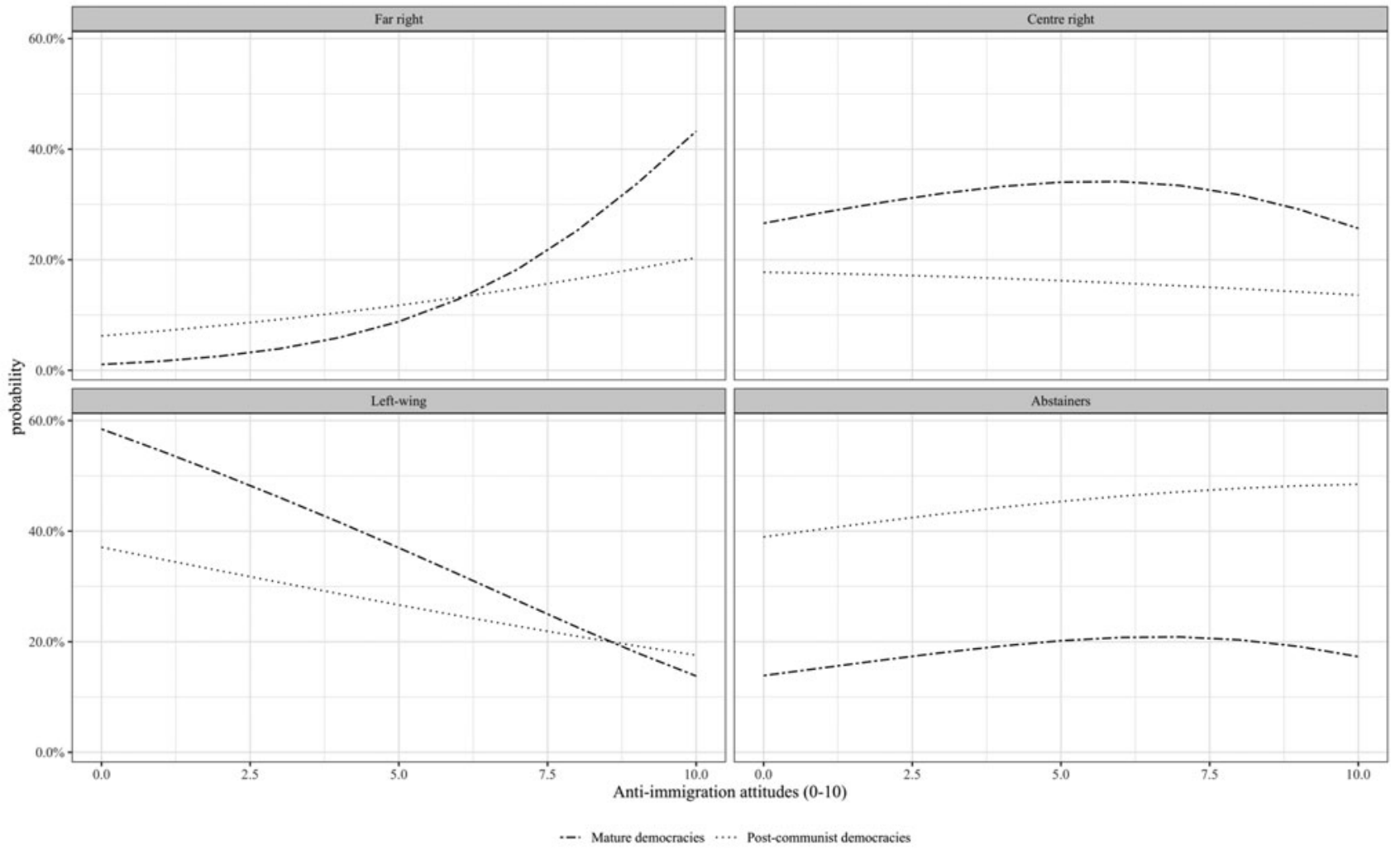

Figure 2. Predicted Probabilities of Belonging to Each of the Four Groups (Far-Right Voters, Centre-Right Voters, Left-Wing Voters, Non-Voters), for Each Level of Anti-Immigrant Attitude 
become more trustful when a far-right party is in power, and other voters become less trustful.

Next, we have estimated our regression models for different subsets of the sample: we dropped countries one at a time to assess how sensitive the results are for outlying cases. These results show that our main findings are robust.

Finally, we have empirically assessed the contribution of each of the three explanatory approaches by evaluating the model fit of separate analyses (see Figure G2 in the online appendix). The results show that the full model, including all three approaches, has a significantly better model fit than any of the three separate models. This indicates that the three explanatory approaches complement each other, rather than substitute each other.

\section{Conclusion and discussion}

This article dissected citizens' support for far-right parties by assessing three explanatory approaches - 'cultural backlash', 'socioeconomic deprivation' and 'protest vote'. This three-fold distinction is common in the scholarship (Arzheimer 2018; Ivarsflaten 2008; Golder 2016). Whereas previous research on the far right predominantly focused on explaining electoral support in Western Europe, we examine to what extent these explanations hold in both new and old democracies in Europe. The article's second main contribution is that it compared the far-right constituency with three other groups of citizens, including non-voters, rather than simply contrasting them with voters for all other parties.

We conclude that explanations for far-right support have parallels in mature and post-communist democracies. The far-right's constituency is particularly distinct from other citizens in terms of its anti-immigrant attitudes and political distrust of supranational governance. Nativist explanations clearly triumph. This confirms earlier studies showing that anti-immigration attitudes are one of the strongest factors for explaining electoral far-right support in Western Europe (Allen 2017b; Ivarsflaten 2008; Rooduijn 2017).

At the same time, our article adds to the existing literature by revealing important differences between post-communist and mature democracies when it comes to who chooses for the far right. Considering the 'cultural backlash' perspective, our findings show that in post-communist democracies, hostility towards immigration accounts to a lesser degree for electoral support for the far right. Its effects on farright voting are considerably smaller (cf. Allen 2017b; Minkenberg 2017).

Equally important, this article nuanced the paradigm of far-right supporters as people who are socioeconomically deprived (see Rooduijn 2017). We conclude that they are not evidently the so-called 'losers of globalization' (Kriesi et al. 2008). This characterization only holds true when we compare far-right voters with centre-right voters. Regarding unemployment and perceived income, we conclude that the electorate of the far right does not differ from people who vote for traditional left-wing parties, in mature or post-communist democracies. Moreover, when compared with non-voters, far-right voters are more educated and have significantly higher perceived incomes (in both Western Europe and CEE).

To conclude, our more fine-grained distinction between groups paid off. This article has refined the debate about what characterizes far-right voters in Europe 
(Ivarsflaten 2008; Rooduijn 2017). We followed the plea for more comparative research between Western and Central Eastern Europe (Bar-On 2018) and illustrated the importance of specific group comparisons in relation to testing theories on electoral support for the far right. All voters for parties other than the far right are too often simply lumped together, while the abstainers are dropped from the research population (Allen 2017a). Our analysis avoided generalizing in respect of mainstream voters by separating centre-right supporters from the left-wing voters. Our dissection furthermore underlines that it is remarkable that non-voters have hitherto been largely ignored in the extensive scholarship on the far right. Threatened socioeconomic status theories, which feature prominently in the literature, seem more appropriate to describe those who abstain from voting (cf. Mudde and Rovira Kaltwasser 2018).

A possible avenue for future research is to achieve more in-depth understanding of the diverse groups of far-right voters. As Ivarsflaten (2008) emphasized, for instance, uniformity in party identification and labelling is essential for comparative research. Especially when considering post-communist democracies, the lack of uniformity in far-right party selection is problematic. Categorization is time- and context-dependent because some mainstream parties radicalized (Bustikova 2018; Minkenberg 2017) and similar parties can be treated differently. For example, Mudde (2017: 6) excluded UKIP and Alternative for Germany (as well as Fidesz and PiS) from the populist radical right family 'because nativism is not a core feature of their party ideology', whereas others included them. Future studies could investigate to what extent the electorates of such 'borderline' cases deviate from 'genuine' far-right parties. A limitation of our study is that we have not elaborated such dissections. In any case, what is considered 'radical' depends on the sociopolitical climate and differs by region (Bustikova 2015; Pirro 2015).

A further limitation of our study is that the analytical distinctions drawn between the cultural backlash thesis, socioeconomic model and protest voting may be somewhat artificial. Labour-market concerns are related to attitudes towards immigrants; the higher one's socioeconomic status, the more favourable one's opinions about foreigners (Mayda 2006). Likewise, certain policy positions might enhance political distrust. Indeed, whether the theoretical framework includes distrust in supranational political institutions in the protest voting approach or in the 'cultural backlash' approach influences the explanatory power of each theoretical approach. We can assume that euroscepticism per se does not predispose voters to support the far right, but that it is linked to nativist beliefs (Arzheimer 2018) and irritation at the EU's promotion of minority rights and sociocultural liberalism (Stanley 2017).

Finally, we focused on the socioeconomic background and attitudes of the European public, the so-called demand side of far-right parties. This study did not tell us much about the supply side. Most importantly, our study leaves open the important question of why far-right parties are more successful in some countries than in others. Or, for that matter, how parties are organized and how they succeed in advertising their agendas (Pytlas 2016). The differences we revealed between far-right supporters and other segments of the European populations in both new and old democracies provide an important yet partial insight into the nature and electoral success of the far right. 
Supplementary material. To view the supplementary material for this article please go to: https://doi.org/ 10.1017/gov.2020.17.

Acknowledgements. Previous versions of this study were presented at the 2018 ECPR General Conference, the 2018 Dag van de Sociologie (annual conference of the Dutch and Flemish sociological associations) and at research meetings of the SILC and SCC research groups (VU Amsterdam). We would like to thank all participants for their helpful comments and suggestions. We particularly would like to thank Matthias Dilling, Harry Ganzeboom, Aat Liefbroer, Arieke Rijken and Sofia Lovegrove for their much-valued insights, feedback and proofreading. We also thank the two anonymous reviewers of Government and Opposition, whose feedback has improved this article considerably.

\section{Notes}

1 A fourth, less successful, approach to explain far-right voting is the 'mass society thesis', which holds that right-wing radicalism arises from weak civil societies and feelings of social distrust and isolation (Berning and Ziller 2017; Rydgren 2011). An earlier, too-lengthy version of our article also included the variables social distrust and lack of political self-efficacy, but these were eventually dropped.

2 This contrast was introduced by Hirschman (1970).

3 Rooduijn et al. (2016) measured what we call 'external efficacy' but labelled this 'political discontent'.

4 Southern Europe is therefore not included. Adding a North vs. South comparison is beyond the scope of our study. Such an additional comparison should acknowledge that some Southern European countries (Portugal, Spain, Greece) have a relatively recent history with dictatorship and are defined as postauthoritarian democracies (Linz and Stepan 1996; Wiarda 2001). Moreover, the politically most relevant change in Southern Europe is the rise of different 'anti-system parties' such as the M5S (Italy), Podemos (Spain) and Syriza (Greece), rather than far-right parties (Ruzza 2018). Furthermore, Ireland and Iceland were excluded because they lack far-right parties, and Russia and Israel because they are neither Western European nor post-communist democracies.

5 Although Germany also includes Eastern Germany, a former communist country, we treat unified Germany as a mature democracy.

6 New left voters account for a relatively small proportion of the electorate. New left parties are not present in three Eastern European countries.

7 Four marginal parties were not included but nevertheless possess both attributes: the People's Party (Belgium), the Movement for France (France), the Way of Courage (Lithuania) and Congress of the New Right (Poland). We have conducted robustness checks to assess whether our results are robust to decisions to either exclude or include certain parties (see online appendix).

8 The items of external political efficacy have different scales between the two ESS rounds. To combine both waves, we rescaled the 11-point scale (ESS 2014) as follows into a 5 -point scale: $0-1=1 ; 2-3=2$; $4-6=3 ; 7-8=4 ; 9-10=5$.

9 We used generalized structural equation model estimation (GSEM) in Stata 14. For all independent variables multicollinearity statistics were inspected, which did not indicate any problems. We estimated fixed effects, which means that we assume that effects of $\mathrm{X}$ on $\mathrm{Y}$ do not vary across different national contexts within one region: we focus on the average effect of an individual-level variable in each region (West and East), rather than the variation of this effect between countries within regions (Sommet and Morselli 2017). 10 All data coding to replicate the results of our article is available at https://github.com/brilstl/paperDEFR.

11 When probabilities are calculated for a variable, the other quantitative variables are kept constant at their means.

\section{References}

Akkerman T, De Lange SL and Rooduijn M (2016) Radical Right-Wing Populist Parties in Western Europe: Into the Mainstream? London: Routledge.

Algan Y, Guriev S, Papaioannou E and Passari E (2017) The European Trust Crisis and the Rise of Populism. Brookings Papers on Economic Activity. BPEA Conference draft, 7-8 September. 
Allen TJ (2017a) Exit to the Right? Comparing Far Right Voters and Abstainers in Western Europe. Electoral Studies 50(1), 103-115.

Allen TJ (2017b) All in the Party Family? Comparing Far Right Voters in Western and Post-Communist Europe. Party Politics 23(3), 274-285.

Arzheimer K (2018) Explaining Electoral Support for the Radical Right. In Rydgren J (ed.), The Oxford Handbook of the Radical Right. Oxford: Oxford University Press, pp. 143-165.

Bakker R, Edwards E, Hooghe L, Jolly S, Marks G, Polk J, Rovny J, Steenbergen M and Vachudova M (2014) Chapel Hill Expert Survey (Version 20151). Chapel Hill, NC: University of North Carolina, www. chesdata.eu.

Bale T (2003) Cinderella and her Ugly Sisters: The Mainstream and Extreme Right in Europe's Bipolarising Party Systems. West European Politics 26(3), 67-90.

Bar-On T (2018) The Radical Right and Nationalism. In Rydgren J (ed.), The Oxford Handbook of the Radical Right. Oxford: Oxford University Press, pp. 17-41.

Berning CC and Ziller C (2017) Social Trust and Radical Right-Wing Populist Party Preferences. Acta Politica 52(2), 198-217.

Betz HG (2004) Exclusionary Populism in Western Europe in the 1990s and Beyond. Geneva: United Nations Research Institute for Social Development.

Betz HG (2019) Facets of Nativism: A Heuristic Exploration. Patterns of Prejudice 53(2), 111-135.

Bovens M and Wille A (2017) Diploma Democracy: The Rise of Political Meritocracy. Oxford: Oxford University Press.

Bustikova L (2015) The Democratization of Hostility: Minorities and Radical Right Actors after the Fall of Communism. In Minkenberg M (ed.), Transforming the Transformation? The East European Radical Right in the Political Process. New York: Routledge, pp. 58-79.

Bustikova L (2018) The Radical Right in Eastern Europe. In Rydgren J (ed.), The Oxford Handbook of the Radical Right. Oxford: Oxford University Press, pp. 565-581.

Bustikova L and Kitschelt H (2009) The Radical Right in Post-Communist Europe: Comparative Perspectives on Legacies and Party Competition. Communist and Post-Communist Studies 42(4), 459-483.

Cavallaro M and Zanetti MA (2020) Divided we Stand: Attitudes, Social Classes, and Voting for the Radical Right after the Great Recession in Europe. Ethnic and Racial Studies 43(2), 313-332.

Dalton RJ and Weldon SA (2005) Public Images of Political Parties: A Necessary Evil? West European Politics 28(5), 931-951.

De Wilde P, Koopmans R, Merkel W, Strijbis O and Zürn M (2019) (eds) The Struggle over Borders: Cosmopolitanism and Communitarianism. Cambridge: Cambridge University Press.

Dunn K (2015) Preference for Radical Right-Wing Populist Parties Among Exclusive-Nationalists and Authoritarians. Party Politics 21(3), 367-380.

Eger MA and Valdez S (2015) Neo-Nationalism in Western Europe. European Sociological Review 31(1), $115-130$.

Gaidytė T (2015) Explaining Political Participation in Mature and Post-Communist Democracies: Why Social Trust Matters? Doctoral dissertation. Amsterdam: Vrije Universiteit Amsterdam.

Gessler T and Kyriazi A (2019) Hungary: A Hungarian Crisis or Just a Crisis in Hungary? In Hutter S and Kriesi H (eds), European Party Politics in Times of Crisis. Cambridge: Cambridge University Press, pp. 167-188.

Golder M (2016) Far Right Parties in Europe. Annual Review of Political Science 19(1), 477-497.

Gómez-Reino M and Llamazares I (2013) The Populist Radical Right and European Integration: A Comparative Analysis of Party-Voter Links. West European Politics 36(4), 789-816.

Hanley S and Sikk A (2016) Economy, Corruption or Floating Voters? Explaining the Breakthroughs of Anti-Establishment Reform Parties in Eastern Europe. Party Politics 22(4), 522-533.

Harteveld E, Van der Meer T and De Vries C (2013) In Europe We Trust: Exploring Three Logics of Trust in the European Union. European Union Politics 14(1), 542-565.

Hay C (2013) Why We Hate Politics. Cambridge: Polity.

Hirschman AO (1970) Exit, Voice, and Loyalty: Responses to Decline in Firms, Organizations, and States. Cambridge, MA: Harvard University Press.

Hooghe M, Marien S and Pauwels T (2011) Where do Distrusting Voters Turn if there is no Viable Exit or Voice Option? The Impact of Political Trust on Electoral Behaviour in the Belgian Regional Elections of June 2009. Government and Opposition: An International Journal of Comparative Politics 46(2), 245-273. 
Howard MM (2003) The Weakness of Civil Society in Post-Communist Europe. Cambridge: Cambridge University Press.

Ignazi P (1992) The Silent Counter-Revolution: Hypotheses on the Emergence of Extreme Right-Wing Parties in Europe. European Journal of Political Research 22(1), 3-34.

Immerzeel T and Pickup M (2015) Populist Radical Right Parties Mobilizing 'The People'? The Role of Populist Radical Right Success in Voter Turnout. Electoral Studies 40, 347-360.

Immerzeel T, Lubbers $\mathbf{M}$ and Coffé $\mathbf{H}$ (2015) Competing with the Radical Right: Distances Between the European Radical Right and Other Parties on Typical Radical Right Issues. Party Politics 22(6), 1-15.

Ivarsflaten E (2005) The Vulnerable Populist Right Parties: No Economic Realignment Fuelling their Electoral Success. European Journal of Political Research 44(3), 465-492.

Ivarsflaten E (2008) What Unites Right-wing Populists in Western Europe? Re-examining Grievance Mobilization Models in Seven Successful Cases. Comparative Political Studies 41(1), 3-23.

Kitschelt H (1995) The Radical Right in Western Europe: A Comparative Analysis. Michigan: University of Michigan Press.

Kochanowicz J (2004) Trust, Confidence, and Social Capital in Poland: A Historical Perspective. In Markova I (ed.), Trust and Democratic Transition in Post-Communist Europe. Oxford: Oxford University Press, pp. 63-84.

Krastev I and Holmes S (2018) Imitation and Its Discontents. Journal of Democracy 29(3), 117-128.

Kriesi H and Pappas TS (2015) (eds) European Populism in the Shadow of the Great Recession. Colchester: ECPR Press.

Kriesi H, Grande E, Lachat ER, Dolezal M, Bornschier S and Frey T (2008) West European Politics in the Age of Globalization. Cambridge: Cambridge University Press.

Linz JJ and Stepan AC (1996) Problems of Democratic Transition and Consolidation: Southern Europe, South America, and Post-Communist Europe. Baltimore: Johns Hopkins University Press.

Lubbers M, Gijsberts M and Scheepers P (2002) Extreme Right-Wing Voting in Western Europe. European Journal of Political Research 41(3), 345-378.

Lucassen G and Lubbers M (2012) Who Fears What? Explaining Far-Right-Wing Preference in Europe by Distinguishing Perceived Cultural and Economic Ethnic Threats. Comparative Political Studies 45(5), 547-574.

Mayda AM (2006) Who is Against Immigration? A Cross-Country Investigation of Individual Attitudes Toward Immigrants. Review of Economics and Statistics 88(3), 510-530.

Mierina I (2011) Political Participation and Development of Political Attitudes in Post-Communist Countries. Doctoral dissertation. Riga: University of Latvia.

Minkenberg M (2017) The Radical Right in Eastern Europe: Democracy under Siege? New York: Springer.

Mudde C (2007) Populist Radical Right Parties in Europe. Cambridge: Cambridge University Press.

Mudde C (2017) Introduction to the Populist Radical Right. In Mudde C (ed.), The Populist Radical Right: A Reader. London: Routledge, pp. 1-10.

Mudde C (2019) The Far Right Today. Cambridge: Polity Press.

Mudde C and Rovira Kaltwasser C (2018) Studying Populism in Comparative Perspective: Reflections on the Contemporary and Future Research Agenda. Comparative Political Studies 51(13), 1667-1693.

Muis J and Immerzeel T (2017) Causes and Consequences of the Rise of Populist Radical Right Parties and Movements in Europe. Current Sociology 65(6), 909-930.

Müller JW (2016) What Is Populism? Philadelphia: University of Pennsylvania Press.

Niemi RG, Craig SC and Mattei F (1991) Measuring Internal Political Efficacy in the 1988 National Election Study. American Political Science Review 85(4), 1407-1413.

Norris P (2005) Radical Right: Voters and Parties in the Electoral Market. New York: Cambridge University Press.

Norris P and Inglehart RF (2019) Cultural Backlash and the Rise of Populism: Trump, Brexit, and Authoritarian Populism. Cambridge: Cambridge University Press.

Oesch D (2008) Explaining Workers' Support for Right-Wing Populist Parties in Western Europe: Evidence from Austria, Belgium, France, Norway, and Switzerland. International Political Science Review 29(3), 349-373.

Oesch D (2012) The Class Basis of the Cleavage between the New Left and the Radical Right. In Rydgren J (ed.), Class Politics and the Radical Right. London: Routledge, pp. 31-51. 
Oesch D and Rennwald L (2018) Electoral Competition in Europe's New Tripolar Political Space: Class Voting for the Left, Centre-right and Radical Right. European Journal of Political Research 75, 783-807. Pateman C (1970) Participation and Democratic Theory. Cambridge: Cambridge University Press.

Pirro AL (2014a) Populist Radical Right Parties in Central and Eastern Europe: The Different Context and Issues of the Prophets of the Patria. Government and Opposition: An International Journal of Comparative Politics 49(4), 600-629.

Pirro AL (2014b) Digging into the Breeding Ground: Insights into the Electoral Performance of Populist Radical Right Parties in Central and Eastern Europe. East European Politics 30(2), 246-270.

Pirro AL (2015) The Populist Radical Right in the Political Process: Assessing Party Impact in Central and Eastern Europe. In Minkenberg M (ed.), Transforming the Transformation? The East European Radical Right in the Political Process. New York: Routledge, pp. 80-104.

Polyakova A (2015) The Backward East? Explaining Differences in Support for Radical Right Parties in Western and Eastern Europe. Journal of Comparative Politics 8(1), 49-74.

Pop-Eleches G (2010) Throwing Out the Bums: Protest Voting and Unorthodox Parties after Communism. World Politics 62(2), 221-260.

Pop-Eleches G and Tucker JA (2017) Communism's Shadow: Historical Legacies and Contemporary Political Attitudes. Princeton: Princeton University Press.

Pytlas B (2016) Radical Right Parties in Central and Eastern Europe: Mainstream Party Competition and Electoral Fortune. London: Routledge.

Rooduijn M (2017) What Unites the Voter Bases of Populist Parties? Comparing the Electorates of 15 Populist Parties. European Political Science Review 10(3), 351-368.

Rooduijn M, Van der Brug W and De Lange SL (2016) Expressing or Fuelling Discontent? The Relationship Between Populist Voting and Political Discontent. Electoral Studies 43(1), 32-40.

Ruzza C (2018) The Radical Right in Southern Europe. In Rydgren J (ed.), The Oxford Handbook of the Radical Right. Oxford: Oxford University Press, pp. 505-520.

Rydgren J (2011) A Legacy of 'Uncivicness'? Social Capital and Radical Right-Wing Populist Voting in Eastern Europe. Acta Politica 46(2), 132-157.

Rydgren J (2013) Introduction: Class Politics and the Radical Right. In Rydgren J (ed.), Class Politics and the Radical Right. London: Routledge, pp. 1-9.

Rydgren J (2017) Radical Right-Wing Parties in Europe. Journal of Language and Politics 16(4), 485-496.

Schneider FM, Otto L, Alings D and Schmitt M (2014) Measuring Traits and States in Public Opinion Research: A Latent State-Trait Analysis of Political Efficacy. International Journal of Public Opinion Research 26(2), 202-223.

Sommet N and Morselli D (2017) Keep Calm and Learn Multilevel Logistic Modeling: A Simplified Three-Step Procedure Using Stata, R, Mplus, and SPSS. International Review of Social Psychology 30(1), 203-218.

Stanley B (2017) Populism in Central and Eastern Europe. In Kaltwasser CR, Taggart PA, Espejo PO and Ostiguy P (eds), The Oxford Handbook of Populism. Oxford: Oxford University Press, pp. 140-160.

Steenvoorden E and Harteveld E (2018) The Appeal of Nostalgia: The Influence of Societal Pessimism on Support for Populist Radical Right Parties. West European Politics 41(1), 28-52.

Szelenyi I and Wilk K (2010) Institutional Transformation in European Post-Communist Regimes. In Morgan G, Campbell JL, Crouch C, Pedersen OK and Whitley R (eds), The Oxford Handbook of Comparative Institutional Analysis. Oxford: Oxford University Press, pp. 565-586.

Trumm S (2018) The 'New' Wave Of Populist Right-Wing Parties in Central and Eastern Europe: Explaining Electoral Support for the Conservative People's Party of Estonia. Representation 54(4), 331-347.

Van der Brug W and Fennema M (2007) Causes of Voting for the Radical Right. International Journal of Public Opinion Research 19(4), 474-487.

Van der Brug W, Fennema M and Tillie J (2000) Anti-Immigrant Parties in Europe: Ideological or Protest Vote? European Journal of Political Research 37(1), 77-102.

Van Kessel S (2015) Populist Parties in Europe: Agents of Discontent? Berlin: Springer.

Verba S, Schlozman KL and Brady HE (1995) Voice and Equality: Civic Voluntarism in American Politics. London: Harvard University Press. 
Werts H, Scheepers P and Lubbers M (2012) Euro-Scepticism and Radical Right-Wing Voting in Europe, 2002-2008: Social Cleavages, Socio-Political Attitudes and Contextual Characteristics Determining Voting for the Radical Right. European Union Politics 14(2), 183-205.

Wiarda HJ (2001) Southern Europe, Eastern Europe, and Comparative Politics: 'Transitology' and the Need for New Theory. East European Politics and Societies 15(3), 485-501.

Zagórski P, Rama J and Cordero G (2019) Young and Temporary: Youth Employment Insecurity and Support for Right-Wing Populist Parties in Europe. Government and Opposition: An International Journal of Comparative Politics, published early online, October, https://doi.org/10.1017/gov.2019.28.

Zhirkov K (2014) Nativist but not Alienated: A Comparative Perspective on the Radical Right Vote in Western Europe. Party Politics 20(2), 286-296.

Ziller C and Schübel T (2015) 'The Pure People' Versus 'the Corrupt Elite'? Political Corruption, Political Trust and the Success of Radical Right Parties in Europe. Journal of Elections, Public Opinion and Parties 25(3), 368-386.

Cite this article: Brils T, Muis J, Gaidyte T (2022). Dissecting Electoral Support for the Far Right: A Comparison between Mature and Post-Communist European Democracies. Government and Opposition: An International Journal of Comparative Politics 57, 56-83. https://doi.org/10.1017/gov.2020.17 